University of Wollongong

Research Online

Faculty of Business - Papers (Archive)

Faculty of Business and Law

$1-1-2012$

Do you see what I see? The role of technology in talent identification

Sharna L. Wiblen

University of Sydney, swiblen@uow.edu.au

Kristine Dery

University of Sydney

David Grant

University of Sydney, david.grant2@unsw.edu.au

Follow this and additional works at: https://ro.uow.edu.au/buspapers

Part of the Business Commons

Research Online is the open access institutional repository for the University of Wollongong. For further information contact the UOW Library: research-pubs@uow.edu.au 


\title{
Do you see what I see? The role of technology in talent identification
}

\author{
Abstract \\ This paper applies a social constructivist lens to understand more about the ways in which technology \\ shapes our understanding of talent management, in particular the processes of talent identification. \\ Specifically, it examines similarities and differences in the identification of talent across a range of \\ business units at a large professional services firm. The findings show that while objective evaluations of \\ talent based on data and information were possible using talent-related technology, managers had \\ subjective and widely different understandings of what constituted talent at the organisation and how to \\ go about identifying it. These different understandings, based on organisational context, personal \\ attitudes, behaviours and past experiences, determined the ways in which the technology and the \\ information it yielded was used. We conclude that the full potential of the talent-related technology and \\ the talent identification processes were unrealised. We discuss the implications of these findings for HR \\ and the management of talent more generally. \\ Disciplines \\ Business \\ Publication Details \\ Wiblen, S., Dery, K. \& Grant, D. (2012). Do you see what I see? The role of technology in talent \\ identification. Asia Pacific Journal of Human Resources, 50 (4), 421-438.
}

This journal article is available at Research Online: https://ro.uow.edu.au/buspapers/940 


\title{
Do You See What I See? Consistency and Technology in Talent Identification
}

\author{
Sharna Wiblen ${ }^{1}$ \\ Work and Organisational Studies, School of Business, University of Sydney \\ Room 414, Institute Building H03, NSW 2006 \\ Sharna.wiblen@sydney.edu.au \\ Kristine Dery \\ Work and Organisational Studies, School of Business, University of Sydney \\ Room 406, Institute Building H03, NSW 2006 \\ Kristine.dery@sydney.edu.au \\ David Grant \\ Work and Organisational Studies, School of Business, University of Sydney \\ Room 416, Institute Building H03, NSW 2006 \\ David.grant@sydney.edu.au
}

\begin{abstract}
:
The management of talent is one of the most important challenges facing HR professionals and the HR function. Despite the continued arguments regarding the importance of managing talent in organisations, our understanding of the way in which organisations identify, recruit and retain those individuals that they consider as 'talent' is limited. This paper seeks to explore the ways in which one organisation undertakes the identification of talent and the role that technology plays in this process. Our findings show that individuals considered as talent were often identified via subjective evaluations rather than via any objective evaluations based on data and information provided by the available talent-related technology. We examine why such subjective evaluations seemed to dominate and the implications of this for talent management. We suggest that the extent to which organisations are capitalising on the potential of technology in talent identification may be influenced by managerial and HR behaviours.
\end{abstract}

Keywords: Talent, talent identification, human resources, technology

\footnotetext{
${ }^{1}$ Corresponding author
} 
The war for talent, talent shortages and changes in other demographic patterns have encouraged organisations, through their human resource function as well senior management, to enhance their understanding of the importance of talent in relation to their business strategy and competitive advantage. This observation is in line with the findings of a report published by the Boston Consulting Group and the World Federation of People Management Associations in September 2010. The report, which surveyed HR professionals from 109 different countries, found that 'Managing talent identifying, attracting, and retaining talent - continues to be the most important future HR topic' (Strack et al., 2010:4).

In order to effectively manage talent, organisations first need to be able to identify who or what is 'talent' and given that talent management is seen as so critical to human resources it is surprising that our knowledge and understanding of the processes and approaches adopted by organisations is limited. Furthermore developments and expansion in the array and sophistication of technology and the internet offers substantially new ways to manage talent and '...to organise a firm's entire HR function' (Laumer, Eckhardt, \& Weitzel, 2010:241). These issues lead us, in this paper, to consider two important and inter-related questions. First how do organisations undertake the identification of talent? Second, what role does technology play in this process? Seeking to answer these questions we draw upon data obtained from a study of the talent management policies and practices in situ at a large Australian based professional service firm. The paper is structured as follows: We first review the emerging literature regarding the importance of talent. We then reflect upon the connections between technology and talent identification. In the next section we present our research design. Following this we then present and reflect upon the experiences of our case organisation. We find that the identification of talent is not as analytical and scientific as the capabilities of the technology might imply, but instead is still somewhat prone to subjective human judgement. Our concluding discussion finds that the extent to which the potential for technology to inform talent identification is unrealised.

\section{The importance of talent and talent management}

The use of the term 'talent management' gained momentum and popularity in the late 1990's. It did so as the 'war for talent' became of increased concern for organisations and, in particular, HR. A McKinsey \& Company's study of 1998 (Chambers, Foulton, Handfield-Jones, Hankin, \& Michaels III, 1998) drew widespread attention to a rising demand for talent-intensive skills that would outpace supply in many industries and markets. Stahl et al (2007) further elaborated by stating that in the context of the late 1990's 'talent management' came to appear synonymous with human capital management and its influence on an organisations strategy. The dominant discourse around talent management tends to stress the drivers behind organisations adopting talent management and thus its importance (see Blass, 2007; Boudreau \& Ramstad, 2005; Buckingham \& Vosburgh, 2001; Calo, 2008; Ready \& Conger, 2007). It also focuses on approaches to talent management (see CIPD, 2006c; Lewis \& Heckman, 2006; McDonnell, Lamare, Gunnigle, \& Lavelle, 2010), and the parties involved in the practice of talent management including HR professionals (see Boudreau \& Ramstad, 2002; Chambers et al., 1998; Devine \& Powell, 2008; Guthridge, Komm, \& Lawson, 2008).

Combining the thoughts and concerns of HR practitioners in Australia, a recent Australian Human Resource Institute (AHRI) report found that their number one priority was Talent Management. AHRI found that 'there was a major focus on talent retention and development during the GFC with $70 \%$ of survey respondents reporting they used performance reviews actively to identify and target upclose and personal actions to keep their best people engaged' (Wilson, 2010:14). This report demonstrates that the identification of an organisations' 'best people' or 'talent' is of real and primary concern for HR.

Although the term 'talent' is applied and used daily by HR practitioners, our knowledge and understanding of what this term means to individuals and organisations is limited. As Lewis and Heckman have observed; 'a review of the literature focused on talent management reveals a disturbing lack of clarity regarding the definition, scope and overall goals of talent management' (Lewis \& Heckman, 2006:139). A further study by McDonnell et al (2010) seems to confirm this multiplicity of definitions. However, despite the overall lack of consensus there does seem to be some agreement that talent, and the characteristics that talented individuals possess, is individualistic and the talents desired will differ between individuals, organisations and industries (Wiblen, Grant, \& Dery, 2010). In an attempt to provide some clarity around the definition of talent management we propose a categorisation through which talent can be conceptualised and identified. The three categories examine talent management in terms of talented individuals, talent in terms of skills identified by the organisation as critical to their business, and finally talent as pivotal roles in the organisation. The first 
category recognises individuals as talent and involves the identification of individuals who are believed to be high performers (see Blass, 2007; CIPD, 2008; Snell, 2008). This view of talent is typically reflected in discussions around recruitment and selection. The second category views talent in terms of particular skills and capabilities and centres upon the organisation's evaluation of particular skills and knowledge as critical to the organisations operations, strategic direction and/ or survival. This category can include individuals and cohorts of employees such as knowledge workers, professional services staff and/ or technical experts (April \& Jappie, 2008; Blass, 2007; CIPD, 2006b, d; Lah, 2009). Individuals that are included in this category are seen to possess attributes and skills that are considered to be hard to replace (CIPD, 2006b). The category thus features predominantly in discussions around development and retention. The third category considers talent in the form of particular functions, or as Boudreau refers to them "pivotal roles" (Boudreau, 2003:21). This category involves the identification of resources and roles that are deemed critical to the strategic success of the organisation. To identify such functions, organisations need to undertake systematic analysis of their business as well as the composition of their human resources. This category focuses more on business analytics and HR metrics and is concentrated around measuring the value of HR investments and how they add value to the organisation. Davenport, Harris and Shapiro (2010) have coined the term 'talent analytics' to draw on the principles of scientific decision making to remove the subjectivity around the process of understanding where talent creates value in the organisation.

Debates regarding the necessity of consistency in talent identification are similarly yet to be resolved. Given the increased emphasis on metrics, more and more academics and practitioners argue that the approach adopted within the organisation needs to be consistent. Busine and Watt expressed such sentiments by stating that 'the identification process needs to be relatively simple but must use consistent criteria across the organisation' (2005:231). Illes, Chuai and Preece (2010) and Stainton (2005) believe that all individuals should go through the same talent identification process while AHRI also observe that the future of talent management will rest upon the extent to which it is based upon clear criteria, processes and procedures and robust and focused metrics that are coupled with hard conversations (Wilson, 2010). Despite such statements and findings, we still know very little about the ways in which organisations define and identify talent and operationalise talent management (lles et al., 2010). One study published by McDonnell et al (2010) indicates that organisations identify and develop talent via informal and ad hoc means, rather than through the systematic and consistent application of any policy or procedures.

\section{The Promise? Talent Management and Technology}

Despite the range of definitions and understanding of what is meant by talent management, the array of technology that is available to the HR function continues to expand and advance in sophistication with some arguing that the future of talent management must involve technology (Davenport et al., 2010; Snell, 2008). The enthusiasm for a relationship between technology and talent management has also been reflected in significant increases in sales of such human capital technologies. Software vendors have benefited from an increase in the number of organisations that have sought to explore the potential role of technology in talent management activities such that in 2010 Taleo, a leader in talent management software, achieved US\$241.8 million in revenue, had more than 5000 customers, and 20 million users of their products (Taleo, 2011).

The increased use of technology for HR activities, including talent management, by organisations has been mirrored by a gradual increase in the number of articles that promote the belief that there is a role for the use of technology in and for talent management. Some proponents on the most general level include Frank and Taylor who state that: 'As technology infiltrates nearly every facet of the workplace, implications for talent management may be profound' (Frank \& Taylor, 2004:39). Similarly Bassi and McMurrer advocate the use of technology and metrics in the management of talent. They argue that through the use of human capital tools, organisations and HR can '...start gauging how well people are managed and developed throughout an organisation' (2007:2). Flowing from this is the belief that an organisation that uses tools and technology in this way will be able to obtain some degree of competitive advantage. In contrast, an organisation that '... manage human capital by instinct and intuition becomes not only inadequate but reckless' (2007:9). More recent research focusing on talent management and technology has found that HR cannot continue to 'confine employee data to its silo' (Davenport et al., 2010:57) but rather enterprise systems are required to gather, analyse and distribute talent analytics throughout the organisation for widespread use by management. Davenport et al describe technology is critical to mastering talent analytics and summarise the functionality required with the acronym Delta: 'access to high quality 
data, enterprise orientation, analytical leadership, strategic targets, and analysts' (Davenport et al., 2010:57).

In sum a number of the compelling reasons as to why organisations should use technology in talent management have been expressed. These include the capacity of the technology to:

- improve decision making (Lengnick-Hall \& Moritz, 2003) by providing and producing information that can establish linkages between human capital assets and the performance of the business.

- produce dynamic, real-time, metrics, analytics and data about an organisation's human capital assets and hence 'talent' In an ever changing context (Williams, 2009).

- provide the potential for an organisation to collect and analyse data to yield knowledge about the effectiveness of various talent-related HR practices and strategies (Lawler, Levenson, \& Boudreau, 2004; Wolfe, Wright, \& Smart, 2006)

- produce sophisticated HR information to maximise the competence and flexibility of employees (Pilbeam \& Corbridge, 2006).

Despite considerable growth in the availability and perceived use of technology in managing human resource and talent management processes, there is still very little research that examines the role that technology plays in talent management and more specifically talent identification. Although several studies and articles address this phenomenon indirectly (see CIPD, 2003, 2004; CIPD, 2005, 2006a; Kirkpatrick, 2005; Wolfe et al., 2006) this research tends to discuss the role and importance of technology and are largely limited methodologically to more quantitative studies. While these studies are able to highlight trends and quantify the number of organisations that may use technology for talent management, they provide little explanation or understandings around how the systems are being used in organisations and the role that they play in talent identification.

Technology can be categorised in a number of ways including electronic Human Resource Management (e-HRM), Human Resource Information Systems (HRIS) (see Williams 2009; Wiblen et al 2010), Enterprise Resource Planning Systems (ERP), information systems and social media. Rather than focusing on one particular form of technology we have opted to look at technology in a more holistic manner to enable a greater understanding of the role of technology more generally. We believe that this is appropriate given our current limited understanding of this phenomenon.

\section{Research Design}

Seeking to enhance our conceptual and empirical understandings of talent and talent management, we undertook an exploratory case study of a professional service firm (PSF) centred around two research questions:

1) How does this organisation identify talent?

2) What role does technology play in the talent identification process?

A case study approach enabled the authors to systematically gather information about social settings, event or group to understand how the subject operates or functions (Berg, 2009). This approach is well suited to the study of complex organisational processes and practices (Allan \& Skinner, 1991; Berg, 2009; Hartley, 2000) and has been used by other similar research projects (see Dery, Grant, Harley, \& Wright, 2006a; Orlikowski, 2002; Tyre \& Orlikowski, 1994).

We selected a professional service firm as our unit of analysis for a number of reasons. Firstly, we believed that organisations, whose service offering is based on the knowledge and capabilities of employees, would be committed to the identification and management of talent. This belief was verified by several of our interviewees with one HR Senior Manager stating, 'Professional services is a very different dynamic when it comes to talent management then your traditional organisations which may have a product or whatever it is, but our product is our people so that does put a significant emphasis around that as well.' Secondly, the knowledge economy will continue to increase in its importance (Wilson, 2010) and hence the significance of talent and talent management in the context of professional service firms is likely to increase. Thirdly, knowledge-based professional service firms are more inclined to be intensive internet and technology users (McDonnell et al., 2010) and thus are more likely to use technology for talent identification. Fourthly 'the war for talent is at its fiercest in high-tech industries' (Economist, 2006:2) and hence we share the assumptions of McDonnell et al (2010) that knowledge intensive organisations such as professional service firms are more likely to have formalised talent management practices. 
Given the exploratory nature of our research questions, we conducted a series of open-ended and semi structured interviews to enhance our understanding and to learn more about how employees in the organisation talked about and understood talent management and the talent identification process. Thirty-three (33) interviews of between 30 and 90 minutes were conducted with members of the organisation between July 2009 and February 2011. Interviewees who participated in our study were selected on the basis of their involvement in the creation, dissemination and management of the organisation's talent management policies and processes. Based on this selection criterion we conducted interviews with members of the senior executive, senior business unit leaders and an array of HR practitioners. The majority of interviewees (27 of the 33) were members of the HR function and as such we were not only able to gain insights into the organisation's approach to talent management and talent identification, but also significant insights into the role of HR itself. These interviews sought to gather rich empirical data that enabled us to build the stories of the interviewees based on their experiences and understanding of talent management within the organisation. The empirical interview data was then transcribed, reviewed by the authors and analysed (Lawler, 1998) through a double hermeneutic process.

To help us better understand our empirical data we applied a social constructivist approach drawing on the social construction of technology (SCOT) literature to provide a lens that enabled us to understand more about how the participants used the technology in context. The SCOT approach challenges the idea that technologies and technological artefacts have a pre-given and fixed meaning and in its place argues that the process, design and selection of technologies are open and can be subjected to contestation (Pinch \& Bijker, 1984). Thus the technology is seen to be characterised by 'interpretative flexibility' and various 'relevant social groups' who articulate and promote particular interpretations of it. This meaning, over time, tends to become accepted and the interpretation of the technology stabilised (Dery, Hall, \& Wailes, 2006b) forming a set of organisational norms and behaviours. Therefore the opinions of respondents can only be understood in the context of individuals and groups comprehending, interpreting, using and engaging with the technologies (Dery et al., 2006b), while also being mindful of the strategic, industry or national context (Martin, 2009). In this context it was important to not only gather the views and experiences of the employees in PSF, but also to observe and gather material that provided further insights into the behaviours and beliefs of the organisation itself. Thus a wide range of publically available material and artefacts were gathered and observed during the research process to add more depth to the organisational story/ case study.

\section{Findings: Talent and Talent Management at PSF}

PSF had over 5000 employees operating in offices around Australia, and in a number of different business units focused on different client offerings. The HR function within this organisation was separated into three functional areas with members of the HR team also being located in different areas of the business: recruitment, national and business unit. There was a diverse array of service offerings provided through the organisation's business units, however, all of the interviewees were committed to the organisation's focus on talent management and understood the potential value of people to PSF's strategic goals. Recognising that future growth could not be achieved without the expansion of the organisations human resources and talent, interviewees talked explicitly about the organisation's programs under the banner of "People Space", the internal brand established by PSF to generate a clear focus and commitment on talent management.

But it is great from the talent management perspective, as your business case for developing people of the future is there. You have got the numbers rather than an aspiration piece where you invest in people as people are your greatest assets. You have actually got, this is how many that we need, and it is there for the taking really. (National HR Manager).

And as I said, [the CEO] is very engaged in the people space and I know that, we have always read a million times that the CEO needs to be engaged for it to be successful, but he is genuinely engaged and so passionate about it. (Business Unit HR Manager).

A commitment to the talent agenda was supported by the CEO and senior executives. This was considered as essential for the success of human resource and talent centric policies and programs and many of the HR managers believed that they were lucky to have to the support and commitment of the wider organisation. Overall talent and talent management was seen to have a number of specific benefits for the organisation that were aligned with its business strategy and which were a source of competitive advantage. For example, senior management highlighted the importance of 
talent in relation to achieving innovation and growth and the provision of high quality services and products to clients.

As part of the senior management's commitment to talent management there had been a significant investment in integrated enterprise systems to support the management team. Oracle's ERP system PeopleSoft had been implemented with the promise that it could offer "best-in-class integrated talent management" with "integrated talent processes and data" (Oracle, 2011). All managers had access to the technology and it was used to a varying extent across the organisation as different managers interacted with the data and its capabilities. For example all managers were required to use Peoplesoft for performance management, particularly in the company-wide requirement for the ranking of top performers. However, discretion was applied to the number of employees that were ranked with some business units ranking their top $10 \%$ while others aimed to cover up to $50 \%$ of their staff. These employees were ranked with the purpose of identifying them as top performers and talent.

Despite the stated commitment to the management of talent, a number of challenges were experienced during the identification of talent process. The organisation did not have a firm wide approach and, as such, responsibility for the identification of talent was left with the individual HR managers and the senior members of their respective business units. The lack of consistent guidelines, criteria or methods to direct this process ensured that each of the different businesses had ultimate power in determining whether it was particular individuals, particular skills and capabilities or particular positions that were to be deemed as important to the organisation and hence talent. Given the power and agency of the individual HR professionals within the different business units to determine the processes of identifying talent, we found that the previous experiences and personal opinions of these managers contributed to the extent to which formality, structure, metrics and technology formed part of the process. We explore these issues further in the next two sections.

\section{Consistency and Technology in Talent Identification}

Some of the HR managers that we interviewed believed that the processes associated with the identification of talent were robust, consistent and facilitated through the use of technology. It was these HR managers that discussed the use and role of different forms of technology within their business unit. For example one business unit, had an established definition for talent identification and systematised tool for the consistent identification of talent. For the past 6 years, this business unit had evaluated individuals based on metrics and information about their performance as well as their potential. It was through technology that this information could be gathered, managed and analysed. The technology was not only seen to play these roles but it could also minimise the influence of subjectivity in a manner which enabled the business unit to be somewhat transparent in their methodology.

Another HR manager attributed the emphasis that their business unit allocated to technology to the nature of the work that it undertook. Conducting business that focused on the creation and management of numbers and financials for their clients had encouraged this business unit to generate metrics regarding an individual's performance. The evaluation of employee performance was managed by technology and used to generate associated talent management reports.

Several other HR managers stated that the primary role of technology in talent management was the ability to generate a ranking of employees. One business unit was able to generate performance metrics and project the potential of their employees. These metrics were then used to rank all individuals within the business and categorise individuals as 'talent'. When asked to reflect upon how this process worked, the HR manager said:

So we use that as a talent identification [tool]. Essentially it ranks people because you get five points for each criteria and out of that, you get a total of 25 and then you can pretty much draw a line under whatever percentage you want to particularly focus on and identify as top talent.

Our evaluation of the differing extent to which technology played a role in talent identification was echoed by some of the HR Managers. One HR Manager was able to shed some light on this phenomenon by describing two contrasting schools of thought which were being enacted within the organisation through members of the HR function. One school focused on the use of metrics and technology. This school was driven by the conscious desire to conduct talent management and human resource management activities in a structured manner through the use of technology. This approach resulted in the use of "... a tool, that you can put millions of things in and spit out results." As alluded 
to above, the greater use of metrics and technology was attributed to the nature of their work and the individual personalities of business leaders responsible for talent evaluation. In dramatic contrast, the second school sought not to "over-engineer" and reflected less focus on systematised processes and gave more currency to greater subjectivity and "gut feel". It was this second school of thought which appeared to have greater salience in the organisation.

New conversations about the potential increased role of technology in the identification and management of talent within the organisations were evident throughout our interviews. Seeking to streamline processes, the need for talent identification had encouraged the HR function to re-evaluate the contributions of technology. Despite the re-evaluation, however, interviewees seemed to perceive a limited role for technology:

The other things that we have looked at it (and) what you are looking at, is the way technology is helping organisations manage talent. We haven't seen too much which helps them identify who the talent are apart from some add-ons to some automated performance management systems. (Business Unit HR Manager).

\section{The Role of 'Seeing'}

Even though some of the HR managers interviewed reflected upon the use and role of technology in the talent identification processes, as discussed above, all of our interviewees stated that decisions about the extent to which individuals were deemed as talent and part of the talent pool, were based on subjective evaluations and 'seeing' talent. While exploring talent identification in the organisation we were intrigued to hear many individuals comment upon the importance of being able to 'see talent.' That is, Senior Business Unit managers in combination with their HR managers would be able accurately evaluate whether an individual was deemed as talent by looking at them and observing their activities. The role of 'seeing talent' was also contrasted with more objective and formally measured techniques such as those that could be facilitated through the use of technology. The extent to which subjectivity and 'seeing' played a role was acknowledged and described in a number of ways although the outcome was the same.

Members of the National HR team were able to provide a more holistic overview of the way in which talent was being identified and confirmed that subjectivity played a primary role in the identification of talent.

"There is a lot of subjectivity, a lot of autonomy of the different leaders and who they feel it is talent" (Recruiting Manager) or that "...the potential to [be talent] is so subjective and open to interpretation (Business Unit HR Manager), and "they [business leaders] are like well I will just tell you who my top talent is" (Business Unit HR Manager).

There was also an assumption that leadership at PFS was synonymous with the ability to pick talent based on their own experiences.

Those people that have risen to the top have tended to have an intrinsic insight into what it takes to get there so they are able to see these traits or behaviours or abilities in others. So they tend to overlay their own experience when they are actually identifying who we think are in the upper echelons of potential. (Business Unit HR Manager).

The use of subjective means to identify talent was not only believed to be the primary approach of the different business units, but also the CEO's preferred approach. Although the CEO and senior management team were clearly committed to talent and the investment in the technology to support talent management several of the HR managers describe the CEO as an individual that shared the belief that one could and should be able to 'see talent'.

[The CEO] has a view that any partner should be able to identify talent like that [and she clicks her fingers]. As in they can just see it. They just know it. (Business Unit HR Manager).

I expect my leaders in each of the individual businesses to tell you the talent is... So he is holding his leaders accountable for a lot of our talent identification piece... (Recruiting Manager). 
We can identify what are some of the characteristics but he is very conscious his partners should know who the talented people are... He said my partners can easily identify the talent. (Business Unit HR Manager).

The identification of talent via subjective means was facilitated through conversations and debates. Many of the HR managers encouraged, organised and conducted meetings involving themselves and the business leaders to identify which individuals were believed to be talent. By focussing on identifying talented individuals, HR managers first allocated to their respective business unit leaders the task of devising a list of individuals whom they personally believed could be considered as talent. The second step involved bringing the business unit leaders together to discuss and debate the specific individuals named on their lists. The ability to discuss and debate talent was seen as beneficial for the organisation. One of the HR managers located in a business unit shared her positive thoughts regarding this process:

The value is actually in the discussion and the debating. Because sometimes it's just one persons opinion. You know a name on a paper...it's good for is to be having these discussions because at least we know who we are talking about. We didn't even have these discussions before. So it helps us to understand talent.

Two additional HR managers echoed the importance and salience attributed to having conversations to identify talent:

"So really I would not say that we have the best but we have got them talking about talent and we have got them thinking about what that looks like" (Business Unit HR Manager).

"But it still comes back to having a discussion, ... having a discussion by the people, with the right people, who expert in people who can then identify who those people are" (Business Unit HR Manager).

\section{Discussions and Conclusions}

The aim of this research was twofold. Firstly we wanted to explore the way in which talent was identified and secondly, what role technology played in this process. Given that our current conceptual and theoretical understandings of talent and talent management are limited, we sought to contribute the insights gained from our empirical research regarding the role of technology in one specific aspect of talent management, that being talent identification.

Our interview data suggests that the role of technology for the identification of talent in our case study was limited and the potential of the technology largely unrealised. Although some of the HR managers located within the different business units stated that they used technology in the talent identification process, most of the decisions about who was identified as talent were based on personal opinions, subjective discussions and debates. As such we believe that overall the identification of talent is achieved through what PFS described as 'seeing'. This term was used extensively in interviews and seems to imply a high degree of subjectivity and social construction. According to the Webster Dictionary, 'seeing' is defined as how we come to know, form a mental opinion of, or perceive the meaning of importance of a person or object. Often described as 'gut-feel' it is an individually constructed variable that implies that some people have a degree of acquired skill or innate knowledge to 'see' things that others can't. This is certainly implied in PSF's talent management process where it is assumed that one of the skills that managers will have is the ability to 'see talent'. Given that subjective opinions play such a primary role in talent identification, we question the extent to which individuals are able to see the same qualities, skills, capabilities and attributes in individuals as talent and hence our question of 'do you see what I see?

While there was substantial investment in technology for the purpose of talent management, it appears that there was an inconsistency of use. Managers were required to rank their employees using the technology but beyond that there was no requirement to conform to the practices embedded in the technology itself. By applying social constructive perspectives we propose that the value the CEO and the senior management team placed on intuition and "gut-feel" of managers to identify talent ran counter to the more structured and analytical processes within the technology. Thus managers attributed little value to the more scientific decision processes of talent identification available through People-soft and instead cultivated the more subjective skills of being able to "see talent". In addition 
the practices that were reinforced across the management team typically used the technology purely for ranking indicators which were subject to discussion and re-working based on more subjective discussion amongst the team. These discussions were considered a critical part of the process and the ability to 'see talent' in employees regarded as talent in itself of successful PSF managers.

Contrary to the arguments proposed by Busine and Watt that 'the identification process needs to be relatively simple but must use consistent criteria across the organisation' (2005:231), we found that the identification process was not simple, nor was it consistent. We attribute this finding to being consciously aware of the context of the organisation and the different client services offered due to the nature of the professional services industry. This enabled us to consider the potential implications that organisational and industry context can have on the conceptualisation, identification and management of talent. Despite the lack of formality and consistency that underpinned talent identification, we believe that the operations of the organisation have not suffered as a consequence, despite the opportunity for technology to add more transparency and objectivity to the process.

Our review of the extant literature revealed that talent can be conceptualised and managed in a number of different ways. Although not the primary focus of this paper, we found that our organisation conceptualised talent as being held with talented individuals. That is, talent as individuals who have demonstrated the ability to be high performers and high potential and who consequently will contribute to the organisation in a positive way (see Blass, 2007; CIPD, 2008; Snell, 2008). The ability for organisations, through their HR function, to articulate who and what is considered as talent is complex and influenced by a number of factors including the nature and focus of the business (Wiblen, Grant and Dery 2010). Our study also shows that the previous experiences, current business activities coupled with personal opinions and beliefs can also have implications for talent management. For our organisation, it was personal and hence subjective opinions and beliefs which drove the identification of talent. This supports our own assumptions that both talent management and the role of technology are socially constructed. While the technological options were readily available to HR managers, the construction of their understanding of talent management and the role of technology was constructed in the context of their working environment, their knowledge and skills, and their understanding of the value contribution of the management of people. HR Managers tended to resort to the subjective processes of talent management that engaged personal preferences and subjective understandings and evaluations of employees. Thus while the opportunities to apply more subjective analytics through the technology existed, this process had not been built into organisational practice. As such the application of the Social Construction of Technology approach helped to enhance our understanding of the role of technology in talent management.

The implications of our findings for HR managers and the HR profession demonstrate that there are both significant opportunities and challenges associated with the use of technology in talent identification and talent management more generally. Although there are a diverse array of arguments regarding the potential contribution of technology to talent management and talent identification, this potential may be largely unrealised. In our organisation we did not find that the pursuit of talent management was driven by the desire to establish a talent decision science as proposed by Boudreau and Ramstad (2005) nor was it focused on metrics. Given that one of the greatest contributions' of technology centres upon the production of human capital metrics, the limited salience attributed to technology is reflected in the limited salience attributed to metrics. Although we believe that there may be a relationship between metrics and the use of technology for talent identification, our study only analysed one organisation and hence the examination of this relationship, as well as multiple case studies or cross-case analysis present potential areas for future research. This study also focused on the identification of talent which was internal to the organisation. We believe that examination of the identification of external talent also present fruitful areas for future research.

In addition we found that primary responsibility for the identification of talent within the organisation rested with members of their HR function demonstrating that HR can, and does, play an important role in the management of talent. Through conversations and collaborations with other senior stakeholders in the organisation, HR continues to have the potential to play a business partner role. Through a focused analysis of talent identification, we found that HR did have prime responsibility for the systems and practices that businesses use to manage people in the workplace (AHRI 2010:5).

The importance attributed to talent management is likely to increase. As competition for those individuals that possess the desired skills and capabilities to pursue and fulfil an organisations business strategy, the more organisations and their senior management will need to focus on the identification, retention and management of talent. Managing talent in a manner which is not only beneficial, but potentially a source of competitive advantage, will require organisations to be proactive. In order to manage talent, organisations first need to think about and define who or what they consider talent to be. Is talent about the individual which was the findings of our empirical research or base $d$ on 
skills and capabilities or particular roles in the organisation? The ability to articulate and define your conceptualisation of talent will then help facilitate the identification of talent. Furthermore, technology, no matter its form, has the potential to change the nature and structure of talent management and it is imperative that $\mathrm{HR}$ practitioners are mindful of this. So many questions regarding talent management, talent identification and technology remain and we would encourage both academics and practitioners to conduct additional empirical research into talent management in Australia and to build on the insights we have offered.

\section{References}

Allan, G. \& Skinner, C. (Eds.). (1991). Handbook for research students in the social sciences London ; New York Falmer Press.

April, K., \& Jappie, A. (2008). Global talent warfare: Line managers are still the determinant Journal for Convergence 9(1): 40-43.

Bassi, L., \& McMurrer, D. (2007). Maximizing Your Return on People Harvard Business Review: 1-10.

Berg, B. L. (2009). Qualitative Research Methods for the Social Sciences (7th ed.). Boston: Allyn \& Bacon

Blass, E. (2007). Talent Management: Maximising talent for business performance. Executive Summary November 2007 1-12. London: Chartered Management Institute,Ashbridge Consulting,.

Boudreau, J. (2003). Sustainability and the Talentship Paradigm: Strategic Human Resource Management Beyond the Bottom Line (CAHRS Working Paper 03-21). Ithaca: New York: Cornell University, School of Industrial and Labor Relations, Center for Advanced Human Resource Studies. .

Boudreau, J. \& Ramstad, P. (2002). Strategic HRM measurement in the 21st Century: From Justifying HR to Strategic Talent Leadership (CAHRS Working Paper 02-15). Ithaca: New York Cornell University, School of Industrial and Labor Relations, Center for Advanced Human Resource Studies.

Boudreau, J. \& Ramstad, P. (2005). Talentship and the New Paradigm for Human Resource Management: From Professional Practices to Strategic Talent Decision Science. Human Resource Planning, 28(2): 17-26.

Buckingham, M., \& Vosburgh, R. (2001). The 21st Century Human Resources Function: It's the Talent, Stupid! Human Resource Planning, 24(4): 17-23.

Busine, M., \& Watt, B. (2005). Succession management: Trends and current practice. Asia Pacific Journal of Human Resources, 43(2): 225-237.

Calo, T. (2008). Talent Management in the Era of the Aging Workforce: The Critical Role of Knowledge Transfer. Public Personnel Management, 37(4): 403-416.

Chambers, E., Foulton, M., Handfield-Jones, H., Hankin, S. M., \& Michaels III, E. G. (1998). The War For Talent McKinsey Quarterly(3): 44-57.

CIPD. (2003). People and Technology London: Chartered Institute of Personnel and Development

CIPD. (2004). People and Technology: Is HR getting the best out of IT? London: Chartered Institute of Personnel and Development

CIPD. (2005). People Management and Technology: Progress and Potential Survey Report June 2005 ed. London: Chartered Institute of Personnel and Development

CIPD. (2006a). HR and Technology: Beyond Delivery Change Agenda Change Agenda ed. London: Chartered Institute of Personnel and Development

CIPD. (2006b). Reflections on Talent Management Change agenda: 22. London: Chartered Institute of Personnel and Development (CIPD), .

CIPD. (2006c). Talent Management: Understanding the Dimensions In C. I. o. P. a. D. (CIPD) (Ed.), Change Agenda. London: Chartered Institute of Personnel and Development

CIPD. (2006d). Talent Management: Understanding the Dimensions: 1-24. London: Chartered Institute of Personnel and Development (CIPD).

CIPD. (2008). Talent Management: an overview July 2008 ed. London: Chartered Institute of Personnel and Development.

Davenport, T., Harris, J., \& Shapiro, J. (2010). Competing on Talent Analytics. Harvard Business Review, 88(10): 53-58.

Dery, K., Grant, D., Harley, B., \& Wright, C. (2006a). Work, organisation and Enterprise Resource Planning systems: an alternative research agenda. New Technology, Work and Employment, 21(3): 199-214. 
Dery, K., Hall, R., \& Wailes, N. (2006b). ERPs as 'technologies-in-practice': social construction, materiality and the role of organisational factors. New Technology, Work and Employment, 21(3): 229-241.

Devine, M., \& Powell, M. (2008). Talent management in the public sector 360 The Ashridge Journal(Autumn 2008): 1-6.

Economist. (2006). The batte for brainpower: A survey of talent The Economist (October 7).

Frank, F. D., \& Taylor, C. (2004). Talent Management: Trends that Will Shape the Future. Human Resource Planning, 27(1): 33-41.

Guthridge, M., Komm, A. B., \& Lawson, E. (2008). Making talent a strategic priority The McKinsey Quarterly, 1: 49-59.

Hartley, J. F. (2000). Case Studies in Organizational Research. In G. Symon, C. Cassell, \& R. Dickson (Eds.), Qualitative Methods in Organizational Research and Practice 208-229. Hove: Psychology Press

Iles, P., Chuai, X., \& Preece, D. (2010). Talent Management and HRM in Multinational companies in Beijing: Definitions, differences and drivers. Journal of World Business, 45(2): 179-189.

Kirkpatrick, D. (2005). IBM Shares Its Secrets Fortune

Lah, T. (2009). Using Talent Supply Chain Management to Overcome Challenges in the Professional Services Market. Workforce Management, 88(3).

Laumer, S., Eckhardt, A., \& Weitzel, T. (2010). Electronic Human Resources Management in an EBusiness Enviornment. Journal of Electronic Commerce Research 11(4): 240-250.

Lawler, E. E., Levenson, A., \& Boudreau, J. W. (2004). HR Metrics and Analytics: Use and Impact. Human Resource Planning, 27(4): 27-35.

Lawler, J. (1998). Choosing a Research Approach: Matching Questions with Methodologies In J. Lawler (Ed.), Writing qualitative research 69-80. Sydney: Hampden Press.

Lengnick-Hall, M., \& Moritz, S. (2003). The Impact of e-HR on the Human Resource Management Function. Journal of Labor Research, 24(3): 365-379.

Lewis, R. E., \& Heckman, R. J. (2006). Talent management: A critical review. Human Resource Management Review, 16(2): 139-154.

Martin, G. (2009). Driving corporate reputations from the inside: A strategic role and strategic dilemas for HR? . Asia Pacific Journal of Human Resources, 47(2): 219-235.

McDonnell, A., Lamare, R., Gunnigle, P., \& Lavelle, J. (2010). Developing Tomorrow's LeadersEvidence of Global Talent management in Multinational Companies Journal of World Business, 45(2): 150-160.

Oracle. (2011). Press Release: Oracle Unveils PeopleSoft Enterprise Human Capital Management 9.1 and PeopleTools 8.50, Vol. http://www.oracle.com/us/corporate/press/034769: Oracle.

Orlikowski, W. (2002). Knowing in Practice: Enacting a Collective Capability in Distributed Organizing. Organization Science, 13(3): 249-273.

Pilbeam, S., \& Corbridge, M. (2006). HR Information Systems and e-enabled HR In S. Pilbeam, \& M. Corbridge (Eds.), People Resourcing: Contemporary HRM in Practice 3rd ed.: 121-140. Harlow, England: Pearson Education Limited

Pinch, T. J., \& Bijker, W. (1984). The Social Construction of Facts and Artefacts: or How the Sociology of Science and the Sociology of Technology might Benefit Each Other. Social Studies of Science (Sage), 14(3): 399-441.

Ready, D. A., \& Conger, J. (2007). Make Your Company a TALENT FACTORY. Harvard Business Review, 85(6): 68-77.

Snell, A. (2008). The Future of Talent Management. Workforce Management, 87(20).

Stahl, G. K., Bjorkman, I., Farndale, E., Morris, S. S., Paauwe, J., Stiles, P., Trevor, J., \& Wright, P. M. (2007). Global Talent Management: How Leading Multinationals Build and Sustain Their Talent Pipeline In INSEAD (Ed.), Faculty \& Research Working Paper 2007/34/OB. France: INSEAD

Stainton, A. (2005). Talent Management: Latest buzzword or refocusing existing processes? . Competency and Emotional Intelligence 12(4): 39-43.

Strack, R., Caye, J.-M., Lassen, S., Bhalla, V., Puckett, J., Espinosa, E., Francoeur, F., \& Haen, P. (2010). Creating People Advantage 2010: How Companies Can Adapt Their HR Practices for Volatile Times, September 2010 ed.: Boston Consulting Group and World Federation of People Management Associations

Taleo. (2011). Taleo: About Us: http://www.taleo.com/company/company-profile.

Tyre, M. J., \& Orlikowski, W. J. (1994). Windows of Opportunity: Temporal Patterns of Technological Adaptation in Organizations. Organization Science, 5(1): 98-118. 
Wiblen, S., Grant, D., \& Dery, K. (2010). Transitioning to a New HRIS: The Reshaping of Human Resources and Information Technology Talent. Journal of Electronic Commerce Research, 11(4): 251-267.

Williams, H. (2009). Job Analysis and HR Planning. In M. Thite, \& M. J. Kavanagh (Eds.), Human Resource Information Systems. Basics, Applications, and Future Directions 251-276. California: SAGE Publications Inc.

Wilson, P. (2010). people@work: The Future of Work and the Changing Workplace: Challenges and Issues for Australian HR Practitioners. Melbourne: Australian Human Resources Institute

Wolfe, R., Wright, P. M., \& Smart, D. L. (2006). Radical HRM innovation and competitive advantage: The Moneyball story. Human Resource Management, 45(1): 111-126. 


\section{Autobiographical Note:}

Sharna Wiblen is a Research Associate at the University of Sydney Business School. Her current research interests focus upon the potential for technology (including human resource information systems (HRIS), electronic human resource management (E-HR) and social media) to inform and benefit talent management and human resource management. She is currently working on a doctorate exploring talent management in Australian organisations.

Kristine Dery is a Senior Lecturer in Work and Organisational Studies at the University of Business School. Her current research examines the impact of mobile technology on the nature of work and individual work/life balance expectations as well as the alignment between human resources and information systems. Her work on technology has been published in New Technology, Work and Employment and Strategic Change.

David Grant is Professor of Organizational Studies, at the University of Sydney Business School. His research interests include examining the impact of ICT related changes on work and organization in Australian workplaces. His work has been published in a range of management and organization journals including Organization Studies, Academy of Management Review, Journal of Applied Behavioral Science, Organization, International Journal of Human Resource Management, New Technology, Work and Employment, Human Relations, Management Communication Quarterly, Journal of Management Studies and British Journal of Management. 